\title{
The Organizational Misfits
}

\section{Patricia A. Suozzi and Sandra S. Kerbel}

\begin{abstract}
Departmental libraries in large systems are often viewed as outsiders and as not fitting neatly into the organizational structure. Most of the writing about these units has focused on whether or not they should exist, rather than on their nature and value to the institutional mission. This article examines the nature of these libraries, their role in the organization, and the type of organizational structure that best enhances their value to the organization.
\end{abstract}

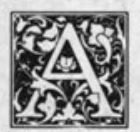

proclamation has been issued. Libraries must evolve from being collection owners to becoming information providers capable of serving as network channelers or coordinators. Librarians have been warned that their traditional organizational structure will need to change if they are to survive and be effective in a future environment of remote users, electronic access, and rapid technological change. Furthermore, they are told that they must look for ways to promote connections between databases, communication networks, scholarly communication, and clients in order to meet what Dilys Morris has called the "greater need for access, interpretation, and brokering."1

The search is on for a new structure or paradigm to effect this role transformation. There is general agreement that "the more important truth about academic libraries is that they are encumbered by record systems and by financial and organizational structures which discourage innovation and make it difficult for them to manage uncertainty." 2 Yet an appropriate or effective role model for the transformation has not been found and validated.

However, the authors believe that a model already exists and should be ex- amined. The model the authors are proposing is that of departmental libraries in a college or university. These libraries are already performing many of these future functions-specialized and tailored services, intensive knowledge of clients, and document delivery. Further, many have operated in an environment where these services were developed without much support from the senior library administration. An examination of departmental libraries will provide insight into how library systems can adopt or integrate the entrepreneurial and flexible mode of operation that characterizes many departmental or branch libraries and seems so necessary to the future growth and effectiveness of libraries in general.

This idea is not as controversial as it may seem. In discussing the future structure of libraries, scholars have actually been describing the operation of many departmental libraries. Some are suggesting that the new structure be organized around groups with many selfcontained tasks and that "the basic management of the groups should be collegial and participative." ${ }^{3}$ Others suggest that "one might also consider access in smaller research-oriented branch libraries, the staff in such branches often seem to understand intuitively the library's place

Patricia A. Suozzi is the Director at Jennie King Mellon Library, Catham College, Pittsburgh, Pennsylvania 15232-2814. Sandra S. Kerbel is Acting Head, Physical Science and Engineering Libraries, University of Pittsburgh, Pennsylvania 15261. 
in the network of research information communication, when it is situated as one 'service station' among many in a department or school."4 David W. Lewis observes that "when access replaces ownership as a significant means of providing scholars and students information, high-quality reference and consultation services will become part of expected institutional support. This will likely lead to an organizational structure based on client-centered work groups as suggested by Charles Martell." ${ }^{\prime 5}$ D. Kaye Gapen predicts that "library organizations will become evolutionary, nonhierarchical, entrepreneurial, and horizontal." 6

In spite of such claims, few librarians have analyzed the role departmental libraries may play in shaping the library of the future. This dearth of analysis can be attributed to the fact that the role of departmental libraries in the library organization is neither well defined nor well understood. As is too often the case, what is not understood is dismissed or conveniently ignored.7 In this case, ignorance may well be terminal. Continuing to view organizational structure through a myopic haze will lead not to evolution but to extinction. This, however, need not be the case. Given the future libraries are facing, librarians should consider whether or not organizational units that exemplify these future paradigms and can act as the foundation upon which to build the "new library" already exist. The first step in this process, then, is to examin: and clarify the nature of departmental libraries and their role in present library organizational structure.

\section{CHARACTERISTICS}

Departmental libraries developed from the specialized needs of specific clienteles. In fact, many of these libraries grew from departmental reading rooms and were formed independently of library administrative plans. This phenomenon of ad hoc libraries is not specific to any discipline but does characterize many departmental libraries. As Edward G. Holley states, "the presence of numerous bootleg or broom closet' libraries on campus ought to indicate to somebody that most university library systems are failing to provide adequate service to segments of the university community." ${ }^{18}$ Departmental libraries in a library system can be viewed as the structured outcome of unmet service needs. As a result, they tend to maintain a close working relationship with their originating departments. Such origins - outside of administrative channels and in close association with departments - can cause library administrators to view departmental libraries as troublesome outsiders. And yet many departmental libraries would not be likely to exist unless they were fulfilling needs common to most academic institutions.

Departmental libraries can be divided into two types: those libraries that are in buildings entirely separate from the central library, and those that are physically located in the central library building but that maintain separate collections. While this paper is mainly concerned with the first type, the second, or hybrid type, also has similar origins and shares many of the same characteristics as the separate departmental library. The chief difference between the two is that the hybrid does not support all of the operational activities, such as circulation or facilities maintenance, that the separate library supports.

Following are some characteristics that tend to identify departmental libraries regardless of type or discipline:

- Readily identifiable and vocal clientele.

- Tightly focused goals and objectives.

- Inter-relatedness of functions.

- Holistic view of service.

- High degree of collegiality and flexibility among staff.

- Close physical proximity to primary user community.

- Entrepreneurial management style, necessitated by both physical and spiritual isolation from other library units.

- Ability to develop and personalize service.

- Identification by primary clientele and staff as part of that academic unit. Given these characteristics, many departmental libraries do not fit well into the 
current hierarchical organization of most library systems. The reporting lines for these libraries are usually vertical and unidirectional. Yet departmental libraries encompass boundary-spanning functions. They are responsible for public services, collection development, and technical services, and such functions often overlap with those of units in a main or central library. As a result, they do not fit well into a hierarchical structure, and as Barbara B. Moran states, "almost all academic libraries are structured in a hierarchical manner." 9 Therefore, they are, in a sense, misfits.

\section{THE DEBATE}

Little in the literature addresses the role of departmental libraries in the knowledge-information process or identifies their place in the organizational structure. Yet, departmental libraries are not being completely ignored. In fact, a large amount of writing has been done on whether departmental libraries should even exist. The problem with these discussions, though, is that the unit of analysis is not the departmental library's effectiveness, but the system's need for tight bureaucratic control. Thus the assumptions on which these discussions are based are biased in that no consideration is given to the needs that promulgated these libraries in the first place or to the ability of these libraries to contribute to the effectiveness of the system.

For example,J. Michael Bruno states that the main disadvantages with departmental organization are administrative:

1. Administrative control (coordination, cooperation, and communication) is difficult to achieve,

2. The cost of administering such branches,

3. The problems of access and security increase. ${ }^{10}$

He dismisses their advantages within two sentences and concludes that "the disadvantages of having such small units as departmental libraries far outweigh any of these advantages." 11 The conclusion of many others is similar: that departmental libraries may fill a need but that they are far too costly.
In 1987 the Journal of Academic Librarianship presented a symposium entitled "Centralization or Decentralization of Library Collections." Thomas D. Watts presented a user's opposition to branch or departmental libraries. He listed five major concerns:

1. The growing interdependence of knowledge

2. Tremendous inconvenience to the user

3. Isolation of collections

4. Expense

5. Communication between departments. $1^{2}$

Implicitly, both Bruno and Watts acknowledge the users' desire for departmental libraries. Yet they see no formal role for them in a library's or institution's mission.

Nevertheless, the assumptions and conclusions of centralization advocates have been questioned and, in a few cases, tested. In terms of administrative control, Anne Woodsworth concludes that "with the acceptance of common citizenship within a university, coordination of policies, personnel practices, budgets, and planning can bring about a decentralized organization that is stronger through its diversity."13 More importantly, Hugh Atkinson predicts that the organizational structure of the future does seem to require an increasing number of smaller, decentralized units and that "these changes will require a new kind of central administrator, a coordinator or evaluator ..." rather than a controller. ${ }^{14}$

\section{COSTS}

The supposed high cost of maintaining departmental libraries, although espoused as dogma, has not been subjected to many empirical studies. One of the few is a study by Snunith Shoham of the Library School Library at the University of California at Berkeley. He studied the cost of maintaining a departmental library in relation to the costs to the user and the university. In his analysis of the costs of the Library School Library, he estimated that 44 percent of the total labor costs for that library would exist 
even if it were not a branch. ${ }^{15}$ In examining material costs, Shoham concluded that only about 7 percent of the materials cost is for duplication of resources. ${ }^{16} \mathrm{He}$ also examined users' costs (i.e., travel costs, time necessary to locate information, waiting time) and concluded that "one would have to impute extremely low values to the hourly value of users' time for their preferences for a convenient, decentralized provision not to be economically justified, once all costs are taken into account."17 Charles R. Martell also calls into question this focus on administrative costs when he states that "the tendency of libraries to measure inputs rather than outputs has been a problem of continuing concern to many librarians."18

The costs, depending on the organizational structure, can be substantial. In addition to materials duplication ... the costs of maintaining departmental libraries can include personnel, equipment, and support for electronic resources.

It may well be that belief in the cost effectiveness of decentralized libraries depends on world view. For example, in the book Austerity Management in Academic Libraries, Joseph Z. Nitecki states that management in an "economy of decline requires efficient operation which in turn implies strictly enforced deadlines and centralization," while Atkinson and Patricia F. Stenstrom in the same book suggest using a decentralized online system to avoid duplication of effort and to recover costs. ${ }^{19}$ Indeed, Atkinson elsewhere proposes that not only may the departmental library be cost-effective but that the amount of administrative managerial overhead may be reduced because "in smaller units much of that 'institutional overhead' is eliminated because the ability to have direct interpersonal interaction is at a high enough level to eliminate the need for formal communication, management and support activities." 20
Undeniably, costs are associated with departmental libraries. The costs, depending on the organizational structure, can be substantial. In addition to materials duplication (which, as Shoham showed, is probably quite low), the costs of maintaining departmental libraries can include personnel, equipment, and support for electronic resources.

Personnel costs tend to be the largest proportion of most library budgets. Many proponents of centralization cite this cost, based on a 1960 s estimate by N. Orwin Rush, as one of the main reasons for centralization. In his article, Rush quotes from a letter by Director of the University of Michigan Library Frederick $\mathrm{H}$. Wagman that "fully 30 percent of the personnel budget of my library system is spent in staffing the many branches in less than adequate fashion." ${ }^{21}$ However, this statement minimizes the fact that personnel would still be needed to perform these functions in a centralized library and ignores users' costs. In fact, a study by Charlene Renner and Barton $\mathrm{M}$. Clark at the University of Illinois showed that staffing patterns were most highly correlated with the circulation and number of volumes in a collection. ${ }^{2}$ This study would seem to indicate that whether a collection was centralized or not has no significant bearing on the number of staff needed. Thus, given that collection size and circulation levels should not vary when collections are centralized, it is unlikely that great savings in personnel costs would be achieved through such a move.

Equipment duplication will exist to some extent in a decentralized system. Additional fax machines, circulation and OPAC terminals, and microform readers will be needed. However, eliminating a departmental library will not completely eliminate these costs since the number of machines for public use (OPAC, microform readers) is depen-dent on the number of users rather than on those users' geographic location. Conversely, some decrease in the number of fax machines and circulation terminals could be realized by centralization. While these savings would be small, nevertheless they could 
allow purchase of fewer but higher quality items that could be shared by more staff in a centralized location.

Duplication of electronic resources and workstations, such as CD-ROM databases, can be expensive. However, recent technological advances will eliminate this problem. The networking of CD-ROMs, the loading of databases into online catalogs, the accessibility of the Internet, and other such developments are providing a decentralized, distributed information environment that permits users to access information from the location of their own choosing rather than forcing them to come to some particular structure. As Woodsworth notes, "When today's technology is utilized fully, the issue of centralized collections will fade into oblivion." ${ }^{23}$ Even in the smallest academic institutions, networking is becoming available and is, therefore, eliminating the need for duplication of resources.

Another criticism of departmental libraries is that access is limited and knowledge is dispersed. Automated union catalogs, shared utilities, and increased reliance by all libraries on resource sharing have made library collections more accessible and decreased reliance on comprehensive, centralized collections. Furthermore, departmental libraries do tend to have integrated collections (contrary to Watts' view) in that the interdisciplinary instructional and research interests of their user communities are reflected in the collection. An engineering collection will not contain only materials from the Library of Congress (LC) T classification, just as an economics collection will contain materials from LC classifications other than H. In fact, as Holley states, "One might well make a case that small well-selected collections located conveniently to users would be more valuable to most of the university community than a large stack of infrequently consulted material centrally housed and scrupulously but expensively cataloged." ${ }^{24}$ Indeed, browsing and serendipity may actually be enhanced in departmental libraries. For example, users trying to browse only for business journals in a current periodicals room filled with thousands of titles from scores of disciplines may find the experience quite frustrating.

\section{THE DATA}

In the ARL SPEC Kit 99, "Branch Libraries in ARL Institutions," ninety-four university libraries reported on their branches, with a total of 1,008 branches reported. Sixty-eight percent of the responding libraries have centralized library systems and 32 percent have decentralized systems. The average number of branches per library in a centralized system was six, while thirteen was the average in a decentralized system. The most common branches were music, mathematics, engineering, physics, chemistry, business, architecture, geology, rare books/special collections, science, and undergraduate libraries. Finally, more libraries reported establishing new branches in the previous five years than closing existing branches. ${ }^{25}$ At least in ARL libraries, branch libraries are a fact and do not seem to be disappearing rapidly.

The idea of maintaining serviceoriented decentralized units is no longer considered heretical. Martell, in his ClientCentered Library, suggests a model of decentralized units that closely resemble the roles and functions of the typical departmental library, while not explicitly discussing departmental libraries.

All of this would imply that the real question for departmental libraries is not whether they should exist. They do and obviously will continue to do so. Nor is the question whether they provide services that fulfill articulated needs - clearly, they do. Rather, the issue is how to design an organizational structure that will allow these nontraditional entities to fit, enhancing and supporting their creative, client-centered character. Resolving this issue will help begin to move the entire library system toward the more proactive, flexible structure needed to fit into a fast-changing information technology environment.

However, changing to a more appropriate structure may be difficult. As Ken Jones points out, "Libraries have been embedded in stableand predictable public 
and academic organizations concerned more with internal regulation and input control than with outgoing enterprise and maximization of effectiveness" and as a result, "bureaucratic organizations tend to suffer from goal displacement, that is, displacement of terminal values by instrumental values. The work, the social relations and the organization itself become their own justifications, with little reference to the clients." ${ }^{26}$

\section{ORGANIZATIONAL STRUCTURES AND MODELS}

The placement of departmental libraries within the organizational structure exemplifies this phenomenon. Little consideration seems to be given to the actual characteristics of the units or the optimal way to position them within the structure to best fulfill user needs. Just as little agreement on the nature of departmental libraries exists, little agreement on their place in the organization occurs. This lack of agreement can be seen in the ARL survey on organization charts (SPEC Kit 129). In analyzing the 61 charts for those libraries that reported having branches, the authors found that 38 percent of the branches reported to an administrator for public services, 13 percent reported to administrators for subject libraries, 10 percent reported to the director, and, in 18 percent, the reporting lines varied by departmental library. ${ }^{27}$

These structures and reporting lines tend to be of four types, which we have labeled: single-dimension functionalism, administrative, subject-divisional, and integrated-collegial. All of them have some advantages, but all of them have the disadvantage of denying (or suppressing) the multifunctional, boundary-spanning nature of these units. Following are generalized descriptions of these three models.

\section{Single-Dimension Functionalism}

The main characteristic of this model is that all departmental libraries report to an administrator of a single functional area in the library system, such as an assistant director for public service. This structure is the predominant one reported by ARL libraries in SPEC Kit 129.
It has the benefit of keeping departmental libraries together in one administrative unit. This type of structure implies that the functional unit within which departmental libraries are placed is the primary, or only, focus of their operations. The problem, of course, is that this placement denies the multifunctional aspects of these units. Departmental libraries by definition are libraries that encompass all of the varied library functions, such as public services, technical services, acquisitions, and outreach. Departmental libraries must regularly interact with many departments on many different levels. Thus, their problems and needs are quite different from those of a department that has only one primary function. Denial of the malfunctional departmental libraries is part of the reason so much conflict and managerial difficulty surrounds these units.

\section{Administrative}

Similar to our first model, this model is also characterized by a hierarchical structure. However, in this case, departmental libraries report to an administrator who has more generalized administrative responsibilities than responsibility for just one function. For example, departmental libraries may report to the head of the largest or central library. To some extent, this model does address the issue of the multifunctionalism of departmental libraries. However, it assumes that the largest library is necessarily the heart of the system. In fact, conflict can arise when libraries are placed in superior/inferior relationships to each other. The head of the central library's main job is to provide services to that clientele. This commitment may result in services to other clienteles being lessened, not because that is objectively appropriate but because that is required to allow heads of the central libraries to do their jobs. Some balance can be achieved by creating an administrator for departmental libraries and an administrator for the central library and placing them on the same hierarchical level. The problem here, especially in large systems, is again the penchant for a hierarchical, control- 
oriented management style. User needs become difficult, if not impossible, to communicate up the hierarchy, and flexibility and creativity in the frontline units are easily suppressed.

\section{Subject-Divisional}

Characterized by dividing the library into units similar to academic departments on the basis of disciplinary boundaries, this structure would organize the system by subject areas with each subject area having an administrator. This model attempts to unify the knowledge base of libraries by basing the structure on the organization's intellectual and educational mission. Thus it draws together resources in terms of knowledge rather than architecture. However, the location of certain functions, such as general reference or technical services, can become problematic. Also, compartmentalizing the entire library system can foster further bureaucratization, leading to a fragmented and overspecialized structure.

These models parallel Henry Mintzberg's structural configurations. His machine bureaucracy configuration in which much formalization occurs and the flow of decision making is top down is similar to the administrative model described above. ${ }^{28}$ His professional bureaucracy with its emphasis on standardization of skills and horizontal and vertical decentralization is similar in some ways to the single dimension functionalism. Our subject-divisional model shares traits with his divisionalized form in that both emphasize standardized outputs and have little vertical decentralization and limited liaison devices. ${ }^{29}$

These structures are based on the configurational view of organizations described by Gregory K. Dow. He defines the configurational view as one that "emphasizes the integration of work tasks under common managerial authority." ${ }^{10}$ Thus, the focus in most organizations on control and centralization of services in analyzing and dealing with departmental libraries clearly fits into the configurational type of structure. Another view of organizational structure that Dow discusses is coactivational.
"The coactivational view stresses recurrent patterns of interaction among organizational participants." ${ }^{11}$ In this type of analysis, the units in an organization are analyzed by the type and intensity of their interactions with other units in the organization. In the coactivational view depart- mental libraries would be considered nodes in a communication network rather than vertical lines on a chart. This type of structure permits a greater flexibility that is better suited to units that span traditional functional boundaries.

\section{Resolving this issue will help begin to move the entire library system toward the more proactive, flexible structure needed to fit into a fast-changing information technology environment.}

Mintzberg describes a similar type of structure when he states that "sophisticated innovation requires a ... very different structural configuration, one that is able to fuse experts drawn from different disciplines into smoothly functioning ad hoc project teams." He calls this structural configuration adhocracy. One type is the operating adhocracy that "innovates and solves problems directly on behalf of its clients," and a key feature is "that its administrative and operating work tend to blend into a single effort." ${ }^{\prime 32}$ This description seems accurate for the boundary-spanning, clientcentered characteristics of the departmental library and is certainly a role model to be emulated not only by departmental libraries but also by all libraries as they begin to position themselves for a very different future. Mintzberg continues, "The adhocracy is clearly positioned in an environment that is both dynamic and complex," and "a dynamic environment calls for organic structure and a complex one calls for decentralized structure." 33

The adhocracy is characterized by little formalization but much liaison, with decision making spread among units, 
and by horizontal job specialization. Within the academic context it could be called an integrated-collegial model. This is our fourth model.

\section{Integrated-Collegial}

This model is characterized by a flat organizational structure in which departmental libraries directly participate in the policy-making management of the organization, rather than reporting through a pyramidal or divisional structure. This model presup- poses a high level of professionalism and a high degree of responsibility, openness, and a holistic world view. Each library or work unit would be responsible as a group for developing services and meeting client needs. The senior administrator for departmental libraries would be replaced by a coordinator, possibly rotating every few years. This model provides a mechanism for considerable input and communication among all members of the organization and allows individuals to contribute their strengths. However, the differing abilities of the various members of the group as well as their willingness to participate fully in the process can be a source of conflict. In addition, maintaining a collective unity can be problematic with a rotating leadership. In spite of some problems, this model allows multifunctional, client-centered units, such as departmental libraries, to fit into the organizational structure without necessarily sacrificing flexibility and creativity. While the other models focus on control, this model emphasizes shared responsibility and enhanced creativity and flexibility. Such an organizational structure can accommodate the autonomous, multifunctional nature of departmental li- braries and channel these energies into support for system-wide goals. By reducing bureaucracy and encouraging participation, much of the divisiveness and fragmentation arising from structural constraints can be eliminated. At the same time, it positions the entire library organization to move into a more proactive, boundary-spanning role within the larger organization.

\section{CONCLUSION}

These models and analyses are intended to open discussion on designing an organizational structure that will fit departmental libraries and will provide the flexibility and entrepreneurial management environment increasingly necessary for libraries, especially large academic libraries, to retain their viability in a time of such great change. In describing the future model for university libraries, D. Kaye Gapen states that "we have to participate, we have to say what we think; we have to put some of our responsibility on the line and be assessed by the people we work with, and that's not so easy. We have to be open and show initiative and courage, and those are qualities that are difficult at times to develop." ${ }^{34}$

Indeed, library users, and especially academic users, are becoming so information and computer literate that with distributed computing and networks, they, rightly, expect to be limited no longer to accessing information and library resources in only one monolithic location.

Thus, the regular call for elimination of departmental libraries may not only be myopic but also illogical and ultimately self-destructive. The call derives more from received wisdom than from a highly centralized organizational structure making sense in the era of a computer on every desk. Indeed, library users, and especially academic users, are becoming so information-and computer-literate that with distributed computing and networks, they rightly expect to be limited no longer to accessing information and library resources in only one monolithic location. This, then, is the challenge for library organizations. It is time for departmental libraries to be considered as models for the library organization rather than as misfits. The systems approach to services and organizational structure of today's departmental libraries may be the characteristics of tomorrow's libraries. 


\section{REFERENCES AND NOTES}

1. Dilys Morris, "Electronic Information and Technology: Impact and Potential for Academic Libraries," College \& Research Libraries 50:56-64 (Jan. 1989).

2. David W. Lewis, "An Organizational Paradigm for Effective Academic Libraries," College \& Research Libraries 47:337-53 (July 1986).

3. Ibid, p.349.

4. John R. Sack, "Open Systems for Open Minds: Building the Library without Walls," College \& Research Libraries 47:535-44 (Nov. 1986).

5. David W. Lewis, "Inventing the Electronic Library," College \& Research Libraries 49:291304 (July 1988).

6. D. Kaye Gapen, "Myths and Realities: University Libraries," College \& Research Libraries 45:350-61 (Sept. 1984).

7. For another recent example of this phenomenon, see Irene B. Hoadley and John Corbin, "Up the Beanstalk: An Evolutionary Organizational Structure for Libraries," American Libraries 21:676-78 (July/Aug. 1990).

8. Edward G. Holley, "Reaction to 'A Brief...,'" Journal of Academic Librarianship 9:201-2 (Sept. 1983).

9. Barbara B. Moran, Academic Libraries: The Changing Knowledge Centers of Colleges and Universities, ASHE-ERIC Higher Education Research Report No. 8 (Washington, D.C.: Assn. for the Study of Higher Education, 1984), p.32

10. J. Michael Bruno, "Decentralization in Academic Libraries," Library Trends 311-17 (Jan. 1971).

11. Ibid., p.314.

12. Thomas D. Watts, "A Brief for Centralized Library Collections," Journal of Academic Librarianship 9:196-97 (Sept. 1983).

13. Anne Woodsworth, "Decentralization Is the Best Principle of Organization Design Where It Fits," Journal of Academic Librarianship 9:198-99 (Sept. 1983).

14. Hugh C. Atkinson, "Impact of New Technology on Library Organization," The Bowker Annual of Library and Book Trade Information, 29th ed. (New York: R.R. Bowker, 1984), p.113.

15. Snunith Shoham, "A Cost-Preference Study of the Decentralization of Academic Library Services," Library Research 4:175-94 (Summer 1982).

16. Ibid., p.182.

17. Ibid., p.188.

18. Charles R. Martell, The Client-Centered Academic Library (Westport, Conn.: Greenwood, 1983), p.71.

19. Joseph Z. Nitecki, "Creative Management in Austerity," Austerity Management in Academic Libraries, p.43-61; Hugh C. Atkinson and Patricia F. Stenstrom, "Automation in Austerity," Austerity Management in Academic Libraries, p.277-85.

20. Hugh C. Atkinson, "A Brief for the Other Side," Journal of Academic Librarianship 9:200-201 (Sept. 1983).

21. N. Orwin Rush, "Central vs. Departmental Libraries," Mountain Plains Library Quarterly 7:3-4 (July 1962).

22. Charlene Renner and Barton M. Clark, "Professional and Nonprofessional Staffing Patterns in Departmental Libraries," Library Research 1:153-70 (1979).

23. Woodsworth, "Decentralization Is the Best Principle," p.199.

24. Holley, "Reaction to 'A Brief...,'" p.202.

25. Branch Libraries in ARL Institutions, ARL SPEC Kit 99. (Washington, D.C.: Assn. of Research Libraries, 1983).

26. Ken Jones, Conflict and Change in Library Organizations: People, Power, and Service (London: Clive Bingley, 1984), p.9, 29.

27. Organization Charts, ARL SPEC Kit 129 (Washington, D.C.: Assn. of Research Libraries, 1986).

28. Henry Mintzberg, The Structuring of Organizations: A Synthesis of the Research (Englewood Cliffs, N.J.: Prentice-Hall, 1979). Machine bureaucracy is defined as a structure in which operating work is routine and work processes are standardized, p.315.

29. Ibid., p.305-467. 
30. Gregory K. Dow, "Configurational and Coactivational Views of Organizational Structure," Academy of Management Review, 13:53-64 (Jan. 1988).

31. Ibid, p.53.

32. Mintzberg, Structuring of Organizations, p.437.

33. Ibid., p.449.

34. Gapen, "Myths and Realities," p.360.

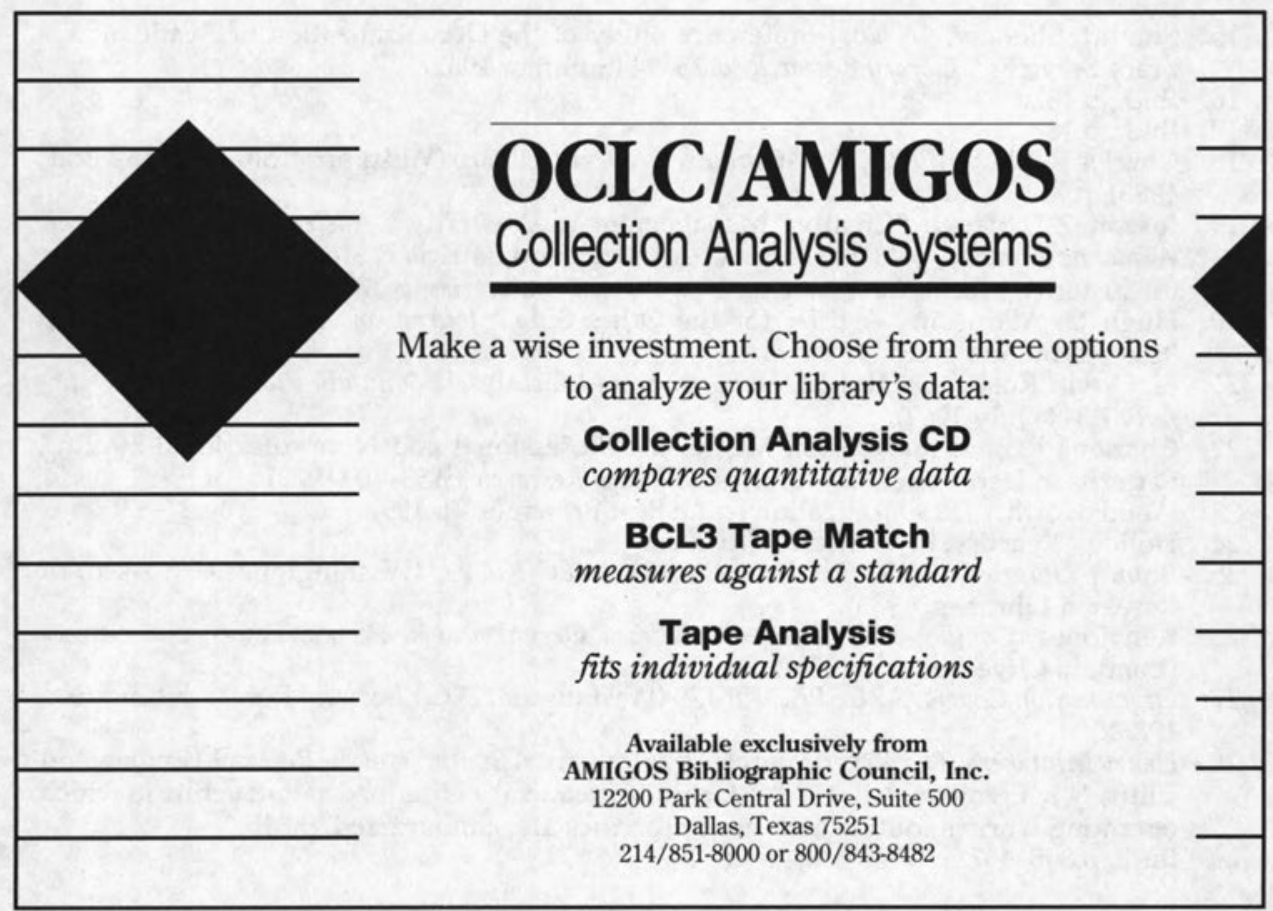

